\title{
Okul Müdürlerinin Karizmatik Liderlik Özelliklerinin Okulların Kurumsal İtibarına Etkisi a
}

\author{
Cüneyt Demir ${ }^{\mathrm{b}, \mathrm{c}}$, Ramazan Yirci ${ }^{\mathrm{d}}$
}

\section{Özet}

$\mathrm{Bu}$ araştırmanın amacı öğretmenlerin görüşlerine göre okul müdürlerinin karizmatik liderlik özelliklerinin okulların kurumsal itibarına etkisini incelemektir. Araştırmada ilişkisel tarama modeli kullanılmıştır. Araştırmanın evrenini 2017 yılı bahar döneminde Kahramanmaraş ili Onikişubat ilçe merkezinde görev yapan 4576 öğretmen oluşturmaktadır. Örneklemi ise evrenden basit tesadüfî örneklem yöntemi ile seçilen 582 öğretmen oluşturmaktadır. Araştırmada verilerin toplanması aşamasında Kişisel Bilgi Formu ile Conger ve Kanungo (1994) tarafından geliştirilen Karizmatik Liderlik Ölçeği ve Karaköse (2006) tarafından geliştirilen Kurumsal İtibar Ölçeği kullanılmıştır. Araştırmada verilerin analizinde Bağımsız Gruplar t testi, Tek Yönlü Varyans Analizi, LSD testi, Games Howell Testi, Pearson Korelasyon Analizi ve Regresyon Analizi uygulanmıştır. Araştırma sonucunda okul müdürlerinin karizmatik liderlik özellikleri ile okulların kurumsal itibarı arasında anlamlı bir ilişki gözlenmiş, okul müdürlerinin karizmatik liderlik özelliklerinin okulların kurumsal itibarının bir yordayıcısı olduğu görülmüştür.
Anahtar Kelimeler

Liderlik

Karizmatik Liderlik

Kurumsal İtibar

Okul Müdürü

Makale Hakkında

Geliş Tarihi: 28.06.2021

Kabul Tarihi: 24.09.2021

Doi: 10.18026/cbayarsos.958569

\section{The Effect of School Managers Charismatic Leadership Features To Schools Corporate Reputation}

\begin{abstract}
The general aim of this research is to investigate the effect of school principals' charismatic leadership features on schools' corporate reputations according to teachers' opinions. The relational survey model was used in the research. 4576 teachers who had been working at schools in Onikișubat district in Kahramanmaras created the universe of this study. 582 teachers working at state schools who were selected with the simple random sample method created the research sample. Personal Information Form and Charismatic Leadership Scale developed by Conger and Kanungo (1994) and Corporate Reputation Scale developed by Karaköse (2006) were used to collect data. Independent Groups t-Test, ANOVA, Pearson Correlation Analysis and Regression Analysis were carried out in the analysis of the data. As the result of this search, a significant relationship was observed between the school principals' charismatic leadership levels and schools' corporate reputation, also seen that school principals' charismatic leadership features are predictors of schools corporate reputation.
\end{abstract}

Keywords

Leadership

Charismatic Leadership

Corporate Reputation

School Principal

About Article

Received: 28.06.2021

Accepted: 24.09.2021

Doi: 10.18026/cbayarsos.958569

a Bu araştırma Doç. Dr. Ramazan Yirci danışmanlığında Cüneyt Demir tarafından hazırlanan yüksek lisans tezinden üretilmiş olup çalışmanın özeti X. Uluslararası Eğitim Araştırmaları Kongresi'nde (Nevşehir) sözlü bildiri olarak sunulmuştur.

b İletişim Yazarı: cuneyt2540@gmail.com.

c Öğretmen, MEB, Kahramanmaraş İl Milli Eğitim Müdürlüğü, http://orcid.org/0000-0002-7145-9260.

d Doç. Dr, Kahramanmaraş Sütçü İmam Üniversitesi Eğitim Bilimleri Bölümü, Eposta: yirci@ksu.edu.tr,

http://orcid.org/0000-0003-4696-7420. 


\section{Giriş}

Örgütsel bağlamda bireysel, kurumsal ve toplumsal sonuçları etkilemede liderlik kavramının önemi yadsınamaz bir gerçektir (Shamir, 1992). Bu gerçek "gizemli bir armağana" sahip olduğu düşünülen "hayattan daha büyük" karakterler olarak görülen karizmatik liderler için düşünüldüğünde daha özel bir anlam ifade etmektedir. Karizmatik liderler bireysel, kurumsal ve toplumsal sonuçları etkileyen bu sonuçlarla birlikte bireysel kurumsal ve toplumsal değişim ve gelişime yön veren, öncülük eden, belirli bir misyon dahilinde onlara vizyon belirleyen ve böylece daha iyi bir geleceğe olan inancı aşılayan liderlerdir (Shamir, House ve Arthur, 1993; Karaköse, 2014; Yirci ve Karaköse, 2010; Yukl, 1999).

Karizmatik liderlik kavramı ile ilgili birçok araştırma ve tanım yapılmıştır. Karizma kavramının yönetim ve işletme alanına girmesini sağlayan ilk araştırmacı,1947 yılında Max Weber olmuştur. Weber karizma kavramını karizmatik yetki biçiminde ele alarak "belirli bir örgütün, belirli bir kaynaktan çıkan emirlere itaat etme ihtimali" şeklinde tanımlamış ve karizmatik liderlikle ilgili geleneksel yetki, karizmatik yetki ve ussal-yasal yetki olmak üzere üç tür yetkiden söz etmiştir. House (1977) yaklaşımında kişisel özellikler, davranışlar ve durumsal ortamlarla ilgili bir kombinasyon oluşturmuş ve karizmatik liderler ile karizmatik olmayan liderleri karşılaştırarak bu ikisi arasındaki farkları belirlemiştir (Gül, 2003). Bass (1990) yaklaşımında karizmatik etkiye sahip liderlerin, takipçilerinin gözünde kendisini olduğundan daha fazla gösterdiğini, takipçilerini kendi inanç ve değerleri doğrultusunda örgütlediğini ve onların tutum ve davranışlarını bu yönde teşvik ettiğini belirtmiştir. Karizma kavramını psikonalitik kavramlarla inceleyen teorisyenler, insanüstü bir kahraman olarak ilahi bir özellik atfedilen ya da ruhani bir figür olarak tapılan bazı karizmatik liderlerin takipçileri tarafından özdeşleşme durumlarını; yansıtma, geçmişe dönüş ve yer değiştirme gibi psikodinamik süreçler kapsamında incelemişlerdir. Meindl (1990) izleyici yönelimli olarak nitelendirdiği yaklaşımında sosyal sirayet (bulaşma) kavramını korku, heyecan, coşku gibi duyguların ve davranışların örgüt üyeleri arasında eş zamanlı olarak yayılması biçiminde ifade etmiştir. Shamir ve arkadaşları yaklaşımlarında (1993) karizmatik liderlikte motivasyonel süreçleri ve takipçilerin bir grup üzerindeki etkilerini incelemişler aynı zamanda ikili ilişkiler konusunda ileri açıklamalar getirmişlerdir. Conger ve Kanungo (1987) Karizmaya Atıf Kuramında ve Antonakis, Fenley ve Liechti (2011)çalışmalarında karizmayı sadece olağanüstü ve özel kişilerde var olan, onların sergileyebileceği bir özellik olarak nitelendirmemişler birçok lider ve yönetici tarafından öğrenilebilir bir olgu olarak tanımlamışlardır.

Karizmatik liderlikle ilgili tanımlar incelendiğinde (Beyer, 1999; Conger ve Kanungo, 1994; Fiol, Harris ve House, 1999; House, 1977; Waldman ve Javidan, 2009) bazı kavramların ortak olduğu görülmektedir. Bu kavramlar, etkileme, hitabet gücü, ikna kabiliyeti ve gönüllülük kavramlarıdır. Ayrıca karizmatik liderlik için eşsiz bir cazibe ve yüksek öz güven duygusu en önemli özellikler arasındadır. Karizmatik lider bu özelliklerini kullanarak, takipçilerini motive eder, onlara amaçlar belirler, heyecanlandırır, güdüler ve bu amaçlar doğrultusunda onları gönüllü olarak harekete geçirir (Koçel, 2007).

Karizmatik liderliğin ortaya çıabilmesi için liderin belirtilen bütün özelliklerinin yanında yaşanılan toplumun içinde bulunduğu sosyal ve siyasi koşullarında etkisi büyük önem arz etmektedir. Yapılan araştırmalar sonucunda toplumun bu koşullarının önemli olduğu değerlendirilmiş ve karizmatik liderlerin genelinin kriz ve kaos ortamlarında ön plana çıktıkları görülmüştür. Güvensizlik, belirsizlik, istikrarsızlık, yönsüzlük ve acizlik 
duygularının insanlara hakim olduğu ve bu duyguların toplumları etkisi altına aldığ durumlarda insanlar, belirsizlik içinde kimliklerini kaybederler oradan oraya savrulurlar, kimlik arayışı içine girerler, onları bir amaç doğrultusunda harekete geçirecek bir kimliğe kavuşturacak olağanüstü bir şahsiyete karizma sahibi bir lidere ihtiyaç duyarlar. İşte bu zor şartlarda karizma, dağılan birliği toparlayacak ve onlarla özdeşleşerek onlara yeni bir kimlik kazandıracaktır (Begeç, 1999, s.88). Nitekim Mustafa Kemal Atatürk, Mahatma Gandhi, Adolf Hitler gibi tarihe mal olmuş en etkili karizmatik liderler, içinde bulundukları toplumların en zor dönemlerinde bu görevi üstlenmişler ve kitleleri peşlerinden sürüklemişlerdir (Cinel, 2008). Karizmatik liderler; bu olağanüstü etkileme yetenekleri sayesinde toplumsal değişim ve gelişimi daha etkin, daha kolay başlatma, bu toplumsal değişim ve gelişime yön verme avantajina sahiptirler.

Toplumların değişimi ve gelişimi için liderlik kadar önemli bir diğer kavram ise son yıllarda kurumların üzerinde sıklıkla durdukları kurumsal itibar kavramıdır (Cornejo, Garcia ve Puente, 2019; Karaköse, 2007). Kurumsal itibar, kurumun paydaşlarının kuruma ilişkin algılarıdır (Barnett, Jermier ve Lafferty, 2006; Fombrun, 1996; Karaköse, 2008). Özellikle bugünün rekabet koşulları göz önünde bulundurulduğunda kurumların faaliyetlerine devam ederek, varlıklarını sürdürebilmeleri açısından kurumsal itibarın çok önemli bir kavram olduğu ve bu sebeple de doğru bir şekilde, dikkatlice yönetilmesi gereken bir kavram olduğu ifade edilebilir (Chun, 2005; Hall, 1993). Kurumsal itibarın iyi yönetilmesi sayesinde, paydaşlar üzerinde olumlu bir bakış açısı yaratmak mümkün olabilecektir. Bunu sağlamak için ise kurumlar, paydaşların istek ve ihtiyaçlarını göz önünde bulundurmalı (Jackson, 2004) ve hamlelerini o doğrultuda gerçekleştirmeye özen göstermelidirler. Paydaşların beklentilerini anlamanın en etkili yolu, kurumların paydaşlarla ilişkilerini etkin bir şekilde sürdürmelerinden ve onlarla olumlu ilişkiler kurmalarından geçmektedir (Cravens ve Oliver, 2006). Kurumların özellikle kendileri açısından öncelikli önem arz eden paydaşların istek ve düşüncelerini de dikkatlice değerlendirmeleri ve yorumlamaları gerekmektedir (Işık, 2011). İyi bir itibar, kuruma ilişkin güven ve dürüstlük gibi algılar yaratırken, kötü itibar, olumsuz varsayımların oluşmasına neden olmaktadır. Olumlu itibar, kurumlara güven, saygı ve sadakat olarak olumsuz itibar ise azalan müşteri memnuniyeti, düşen kârlar ve nihayetinde küçülen bir kurum olarak geri dönmektedir. Bu kapsamda olumlu bireylerde örgütün yeni özelliklerine, davranışlarına ve ürünlerine ilişkin çoğu zaman mevcut olandan daha fazla olumlu değerlendirmelerin yapılmasını sağlamaktadır (Tak ve Çiftçioğlu, 2009).

Günümüz rekabet ortamında kurumların kısa veya uzun vadeli hedeflerini gerçekleştirebilmeleri, varlıklarını devam ettirebilmeleri ve geliştirmeleri için paydaşlarının ve toplumun gözünde itibar kazanması ve kazanılan bu itibarı iyi yönetmesi kurumlar açısından hayati öneme sahiptir. Okulların birer eğitim kurumu olduğu düşünüldügünde okullar açısından kurumsal itibarı ifade edecek olursak okulun iç ve dış paydaşlarının okulla ilgili iyi ya da kötü algılarının toplamıdır şeklinde ifade edebiliriz (Karaköse, 2006). Okullar bölgelerinde etkili, verimli ve tercih edilen bir okul olmak istiyorlarsa öncelikle iyi bir itibar kazanmalı ve bu itibarı iyi yönetmelidirler. Okullar bu itibarı kazanabilmek için hizmet ve yönetim kalitesine sahip olmalı, ürün ve hizmetler konusunda yeterli olmalı finansal açıdan güçlü olmalı, olumlu bir çalışma ortamı oluşturmalı ve toplumsal sorumluluklarını yerine getirmelidir. Okulların bu itibarı kazanması ve etkili olarak yönetebilmesi için okul müdürlerinin bilgi, yetenek ve tecrübeleri büyük önem arz etmektedir. 
Okullar paydaşlarını toplumsal yapının içindeki insanların oluşturduğu birer eğitim kurumları olarak faaliyet göstermektedirler. Dolayısıyla toplumsal değişme ve gelişmeler hususunda okullar ile toplum arasında karşılıklı bir etkileşim söz konusudur. Okulların birer eğitim kurumu oldukları düşünüldüğünde bu etkileşimde daha çok etkileyen tarafın okul tarafı olması gerekmektedir. Yani okullar dünyada yaşanan gelişmeleri yakından takip ederek bütün paydaşlarını ve içinde yaşadıkları toplumu, bu gelişmelerle ilgili bilgilendirmeli etkilemeli ve onları yönlendirmelidirler. Okullar bu görev ve sorumlulukları üstlenirken okullar açısından en önemli unsur hiç şüphesiz okula liderlik eden, okulu yöneten, okuldaki çalışanlarla iletişim kurarak onları organize eden ve okul örgütünü başarılı bir düzeye ulaştırmayı hedefleyen kişiler yani okul müdürleridir (Başar, 1995, Yirci vd., 2014; Yirci ve Kurtulmuş, 2018). Bu kadar önemli bir görevi üstlenen okul müdürlerinin toplumsal yapıdaki değişim ve gelişimin öncelikle eğitim kurumlarından başlayacağı ilkesini göz önünde bulundurması ve okulu paydaşları açısından daha çekici ve etkileyici bir kurum haline getirmesi gerekmektedir (Aydoğar ve Yirci, 2020; Yirci ve Berk, 2021). Okul müdürleri öncelikle etkili bir yönetim tarzı sergileyerek okuldaki öğretmenleri, öğrencileri, velileri etkileyebilmeli onları peşinden sürüklemeli ve bunu topluma yaymalıdır. Okul müdürlerinin bu hedeflerine ulaşması için bir karizmaya, etkili hitabet gücüne, yüksek ikna kabiliyetine ve olağanüstü etkileme yeteneğine yani karizmatik liderlik özelliklerine sahip olması önem arz etmektedir. Okullarda itibar kazanmak, kazanılan itibarı korumak ve onu iyi yönetmek büyük önem arz etmektedir. Okullar açısından kurumsal itibar okulun paydaşlarının okulla ilgili algılarının toplamıdır şeklinde ifade edilirken, okulda itibar yönetimi ise en genel anlamıyla okulun paydaşlarının okulla ilgili algılarının yönetilmesi olarak ifade edilmektedir. Okullarda etkili ve verimli bir kurumsal itibar yönetimi sergilemenin yolu, hem kurumsal itibarın bir bütün olarak değerlendirilmesi hem de paydaşların algılarının iyi yönetilmesinden geçmektedir. Bu itibarı yönetmek ve arttırmak hiç şüphesiz okulların en önemli paydaşlarından biri olan okul müdürlerine düşmektedir. $\mathrm{Bu}$ düşünceden hareketle araştırmanın genel amacl; öğretmenlerin görüşlerine göre okul müdürlerinin karizmatik liderlik özelliklerinin okulların kurumsal itibarına etkisini incelemektir. Bu genel amaç doğrultusunda aşağıdaki sorulara yanıt aranmıştır:

a. Öğretmenlerin görüşlerine göre okul müdürlerinin karizmatik liderlik özellikleri ne düzeydedir?

b. Öğretmenlerin görüşlerine göre okulların kurumsal itibarı ne düzeydedir?

c. Öğretmenlerin görüşlerine göre okul müdürlerinin karizmatik liderlik özellikleri ile okulların kurumsal itibarı öğretmen cinsiyet, öğretmen eğitim durumu, öğretmen branş, öğretmen okul türü, öğretmen kıdem, müdür eğitim durumu, müdür kıdem, değişkenlerine göre farklılaşmakta mıdır?

d. Öğretmenlerin görüşlerine göre okul müdürlerinin karizmatik liderlik özelliklerinin okulların kurumsal itibarına etkisi var mıdır?

\section{Yöntem}

\section{Araştırma Modeli}

Öğretmenlerin görüşlerine göre okul müdürlerinin karizmatik liderlik özeliklerinin okulların kurumsal itibarına etkisinin incelendiği bu araştırmada betimsel tarama modellerinden ilişkisel tarama modeli kullanılmıştır. İlişkisel tarama modeli iki veya daha çok sayıda 
değişken arasında birlikte değişimin varlığını ve derecesini belirlemeyi amaçlayan araştırma modelidir (Karasar, 2010).

\section{Evren ve Örneklem}

Araştırmanın evrenini 2017 yılı bahar döneminde Kahramanmaraş ili Onikişubat ilçe merkezinde ilkokul, ortaokul ve liselerde görev yapmakta olan 4576 öğretmen oluşturmaktadır. Araştırmanın örneklemini ise, evrenden basit tesadüfi örneklem yöntemi ile seçilen 582 öğretmen oluşturmaktadır. Tanımlanan evren listesinden örnekleme birimlerinin tesadüfi olarak çekilmesi basit tesadüfi örneklem olarak adlandırılır (Büyüköztürk, 2007). Araştırmaya katılan öğretmenlerin demografik özelliklerine ilişkin verilerin dağılımı Tablo 1'de verilmiştir.

Tablo 1. Öğretmenlerin Sosyo-Demografik Özelliklerinin Frekans ve Yüzde Değerleri

\begin{tabular}{llcr}
\hline Değişkenler & Gruplar & N & \% \\
\hline \multirow{2}{*}{ Cinsiyet } & Erkek & 284 & 48.80 \\
& Kadın & 298 & 51,20 \\
\hline \multirow{2}{*}{ Eğitim Durumu } & Ön lisans & 43 & 7.40 \\
& Lisans & 487 & 83.70 \\
\hline \multirow{3}{*}{ Branş } & Lisansüstü & 52 & 8.90 \\
\hline \multirow{3}{*}{ Okul Türü } & Sinıf Öğretmeni & 184 & 31.60 \\
& Branş Öğretmeni & 398 & 68.40 \\
\hline İlkokul & 222 & 38.10 \\
& Ortaokul & 213 & 36.60 \\
& Lise & 147 & 25.30 \\
\hline & $0-5$ yıl & 71 & 12.20 \\
& $6-10$ yıl & 111 & 19.10
\end{tabular}

Araştırmanın yapıldığı okulların, okul müdürlerinin demografik özelliklerine ilişkin verilerin dağılımı tablo 2'de verilmiştir. 
Tablo 2. Okul müdürlerinin Sosyo-Demografik Özelliklerinin Frekans ve Yüzde Değerleri

\begin{tabular}{llcr}
\hline Değişkenler & Gruplar & $\mathbf{N}$ & \% \\
\hline \multirow{3}{*}{ Eğitim Durumu } & Ön lisans & 1 & 17 \\
& Lisans & 1060 & 60.70 \\
& Lisansüstü & 10 & 35.70 \\
\hline \multirow{3}{*}{ Kıdem } & $10-15$ yıl & 4 & 14.30 \\
& $16-20$ yıl & 8 & 28.60 \\
& $21-25$ yıl & 7 & 25.00 \\
& $26-30$ yıl & 4 & 14.30 \\
& 31 ve üzeri & 5 & 17.80 \\
\hline
\end{tabular}

\section{Veri Toplama Araçları}

\section{Kişisel Bilgi Formu}

Araştırmanın demografik özellikleri ile ilgili bilgi edinmek amacıyla araştırmacı tarafından geliştirilen Kişisel Bilgi Formu; araştırmaya katılan öğretmenlerin demografik özelliklerini betimlemeye yönelik beş madde (Cinsiyet, Branş, Eğitim Durumu, Kıdem, Okul Türü) ve araştırmanın yapıldığı okul müdürlerinin demografik özelliklerini betimlemeye yönelik iki madde (Eğitim Durumu, Kıdem) olmak üzere toplam yedi maddeden oluşmaktadır.

\section{Karizmatik Liderlik Ölçeği}

Araştırmada öğretmenlerin görüşlerine okul müdürlerinin karizmatik liderlik özelliklerini belirlemek amacıyla Conger ve Kanungo (1994) tarafından beşli likert tarzda hazırlanan yirmi madde ve altı alt boyuttan (vizyon belirleme, çevresel duyarlılık, sıra dışı davranışlar sergileme, kişisel risk üstlenme, üye ihtiyaçlarına duyarlılık gösterme ve statükoyu sürdürmeme) oluşan Karizmatik Liderlik Ölçeği kullanılmıştır. Ölçek Aykanat (2010) tarafından Türk kültürüne uyarlanmıştır. Conger ve Kanungo güvenirlik katsayısı Cronbach Alpha değerini .80 olarak hesaplamışlardır. Aykanat (2010) ise güvenirlik katsayısı Cronbach Alpha değerini .87 olarak hesaplamış ve oldukça güvenilir olduğunu belirtmiştir. Bu araştırmada ölçeğin geneli için güvenirlik katsayısı Cronbach Alpha değeri .96 olarak hesaplanmiştır.

\section{Kurumsal İtibar Ölçeği}

Araştırmada öğretmenlerin okullara yönelik kurumsal itibar algılarını ölçmek amacıyla Karaköse (2006) tarafından geliştirilen, Kurumsal İtibar Ölçeği kullanılmıştır. Kurumsal İtibar 
Ölçeği beşli likert tarzda hazırlanmış kırk madde ve yedi alt boyuttan oluşmaktadır. Bu alt boyutlar; hizmet kalitesi, yönetim kalitesi, finansal sağlamlık, çalışma ortamı, toplumsal sorumluluk, duygusal çekicilik ve kurumsal etik alt boyutlarıdır.

Kurumsal İtibar Ölçeği güvenirliği ile ilgili olarak Karaköse güvenirlik katsayısı Cronbach Alpha değerini .89 olarak hesaplamışlardır. Ölçeğin tüm boyutlarının toplam iç tutarlılık katsayısı Cronbach Alpha .93 olarak hesaplanmış ve bu düzey yeterli görülmüştür (Karaköse, 2006). Bu araştırmada ölçeğin geneli için güvenirlik katsayısı Cronbach Alpha değeri .96 olarak hesaplanmıştır. Alt boyutlarının güvenirlik katsayısı incelendiğinde Cronbach Alpha değeri hizmet kalitesi alt boyutunda .82, yönetim kalitesi alt boyutunda .92, finansal sağlamlık alt boyutunda .71, çalışma ortamı alt boyutunda .89 , toplumsal sorumluluk alt boyutunda .79 , duygusal çekicilik alt boyutunda .91 ve kurumsal etik alt boyutunda .87 olarak hesaplanmıştır. Ölçeğin genelinde ve alt boyutlarında Cronbach Alpha değeri incelendiğinde güvenilir olduğu söylenebilir.

\section{Verilerin Toplanması ve Analizi}

Araştırmada elde edilen veriler araştırmacı tarafından kontrol edilerek bilgisayar ortamına aktarılmış ve SPSS 22.0 istatistik paket programı kullanılarak çözümlenmiştir. Verilerin analizinde öncelikle verilerin normal dağılım gösterip göstermediği incelenmiş, verilerin dağılımı QQ plot, basıklık (Kurtosis) 0.131, standart hatası (Std.Error of Kurtosis) 0.202, ve çarpıklık (Skewness) -0.393, standart hatası (Std. Error of Skewness) 0.101 olduğu görülmüş ve genel geçer bir kural olarak, çarpıklık katsayısını ve basıklık katsayısını sırasıyla, çarpıklığın ve basıklığın standart hatasına böldüğümüzde çıkan değerler -1.96 ile +1.96 arasında kalıyorsa dağılımın normal kabul edileceği (Can, 2016) değerlendirilerek verilerin normal dağılım gösterdiği kabul edilmiş ve parametrik testlerin yapılabileceği görülmüştür. Verilerin analizinde Bağımsız Gruplar t testi, Tek Yönlü Varyans Analizi, LSD Testi Games Howell Testi, Pearson Korelasyon Analizi ve Regresyon Analizi uygulanmıştır.

\section{Bulgular}

\section{Karizmatik Liderlik Ölçeğine İlişkin Bulgular}

Okul yöneticilerinin karizmatik liderlik özelliklerine ilişkin betimsel değerler ölçekteki her bir alt boyutu kapsayacak biçimde Tablo 3'te sunulmuştur.

Tablo 3. Okul Müdürlerinin Karizmatik Liderlik Özelliklerine Yönelik Betimsel Değerler

\begin{tabular}{lllr}
\hline Ölçek/Alt Boyutlar & $\mathbf{N}$ & $\underline{X}$ & SS \\
\hline Karizmatik Liderlik & 582 & 3.64 & 0.82 \\
Vizyon Belirleme & 582 & 3.65 & 0.97 \\
Çevresel Duyarlılık & 582 & 3.74 & 0.90 \\
Sıra Dişı Davranışlar Sergileme & 582 & 3.44 & 0.94 \\
Kişisel Risk Üstlenme & 582 & 3.46 & 1.01
\end{tabular}


Üye İhtiyaçlarına Duyarlılık

582

Statükoyu Sürdürmeme

Tablo 3 incelendiğinde öğretmenlerin görüşlerine göre karizmatik liderlik ölçeği genel ortalamasının ( $\underline{\boldsymbol{x}}=3.64)$ katılıyorum düzeyinde olduğu görülmektedir. Alt boyutlar incelendiğinde vizyon belirleme alt boyutu $(\underline{x}=3.65)$, çevresel duyarlılık alt boyutu $(\underline{x}=3.74)$, üye ihtiyaçlarına duyarlılık gösterme alt boyutu $(\underline{x}=3.74)$, statükoyu sürdürmeme alt boyutu $(\underline{x}=3.82)$ ortalamasının katıliyorum düzeyinde, sıra dışı davranışlar sergileme $(\underline{x}=3.44)$ ve kişisel risk üstlenme alt boyutlarında ise fikrim yok düzeyinde olduğu görülmektedir.

Tablo 4. Öğretmenlerin Cinsiyet Değişkenine Göre "Karizmatik Liderlik Ölçeği”' Bağımsız Gruplar t-Testi Sonuçları

\begin{tabular}{lllccccc}
\hline Ölçek & Cinsiyet & $\mathbf{N}$ & $\underline{X}$ & SS & Sd & T & P \\
\hline \multirow{2}{*}{ Karizmatik Liderlik } & Erkek & 284 & 3.72 & 0.87 & 580 & 2.370 & $0.018^{*}$ \\
& Kadın & 298 & 3.56 & 0.75 & & & \\
\hline
\end{tabular}

${ }^{*} \mathrm{p}<.05$

Tablo 4 incelendiğinde okul müdürlerinin karizmatik liderlik ölçeğinden aldıkları puanların aritmetik ortalamalarında, öğretmenlerin cinsiyet değişkenine göre istatistiksel olarak anlamlı farklılık görülmektedir ( $\mathrm{t}=2.370, \mathrm{p}<.05)$. Bu analiz sonucunda, kadın öğretmenlerin aritmetik ortalama puanlarının, erkek öğretmenlerin aritmetik ortalama puanlarından anlamlı olarak daha yüksek olduğu tespit edilmiştir.

Tablo 5. Öğretmenlerin Eğitim Durumu Değişkenine Göre "Karizmatik Liderlik Ölçeği" Tek Yönlü Varyans Analizi Sonuçları

\begin{tabular}{|c|c|c|c|c|c|c|c|c|c|}
\hline $\begin{array}{l}\text { Eğitim } \\
\text { Durumu }\end{array}$ & $\mathbf{N}$ & $\underline{X}$ & $S$ & $\begin{array}{l}\text { Varyansın } \\
\text { Kaynağı }\end{array}$ & $\begin{array}{c}\text { Kareler } \\
\text { Toplamı }\end{array}$ & Sd & $\begin{array}{c}\text { Kareler } \\
\text { Ortalaması }\end{array}$ & $\mathbf{F}$ & $\mathbf{P}$ \\
\hline Ön Lisans & 43 & 4.15 & 0.57 & Gruplararası & 13.623 & 2 & 6.811 & 10.369 & $0.00^{*}$ \\
\hline Lisans & 487 & 3.62 & 0.80 & Gruplariçi & 380.332 & 579 & 0.657 & & \\
\hline $\begin{array}{l}\text { Yüksek } \\
\text { Lisans }\end{array}$ & 52 & 3.44 & 0.98 & Toplam & 393.954 & 581 & & & \\
\hline Toplam & 582 & 3.64 & 0.82 & & & & & & \\
\hline
\end{tabular}

${ }^{*} \mathrm{p}<.05$

Tablo 5 incelendiğinde okul müdürlerinin karizmatik liderlik ölçeğinden aldıkları puanların, öğretmenlerin eğitim durumu değişkenine göre istatistiksel olarak anlamlı farklılık gösterip göstermediğini belirlemek için uygulanan Tek Yönlü Varyans Analizi sonucunda istatistiksel olarak anlamlı farklılık görülmektedir $(\mathrm{F}=10.369$, p<.05). Bu anlamlı farklılı̆̆ın kaynağını belirleyebilmek amacıyla tamamlayıcı post-hoc tekniklerini kullanabilmek için Levene's Testi uygulanmış olup varyansların homojen olmadığı tespit edilmiştir (Levene F=6.894, p<.05). 
Varyansların homojen olmadığı durumlarda uygulanan post-hoc tekniklerinden Games Howell Çoklu Karşılaştırma Testi sonucunda, karizmatik liderlik ölçeğinde öğretmenlerin eğitim durumu değişkenine göre ön lisans mezunu ile lisans ve yüksek lisans mezunu puanları arasında istatistiksel olarak anlamlı bir farklılık görülmüştür. Bu analiz sonucunda ön lisans mezunu öğretmenlerin puan ortalamalarının, lisans ve yüksek lisans mezunu öğretmenlerin puan ortalamalarından yüksek olduğu tespit edilmiştir.

Tablo 6. Öğretmenlerin Branş Değişkenine Göre “Karizmatik Liderlik Ölçeği” Bağımsız Gruplar t-Testi Sonuçları

\begin{tabular}{llllllll}
\hline Ölçek & Branş & $\mathbf{N}$ & $\underline{X}$ & SS & Sd & T & P \\
\hline \multirow{2}{*}{ Karizmatik Liderlik } & Sınıf & 184 & 3.97 & 0.75 & 580 & 6.785 & $0.00^{*}$ \\
& Branş & 398 & 3.49 & 0.81 & & & \\
\hline
\end{tabular}

${ }^{*} \mathrm{p}<.05$

Tablo 6 incelendiğinde okul müdürlerinin karizmatik liderlik ölçeğinden aldıkları puanların aritmetik ortalamalarında, öğretmenlerin branş değişkenine göre istatistiksel olarak anlamlı farklılık görülmektedir ( $\mathrm{t}=6.785, \mathrm{p}<.05)$. Bu analiz sonucunda, sınıf öğretmenlerinin aritmetik ortalama puanlarının, branş öğretmenlerinin aritmetik ortalama puanlarından anlamlı olarak daha yüksek olduğu tespit edilmiştir.

Tablo 7. Öğretmenlerin Okul Türü Değişkenine Göre "Karizmatik Liderlik Ölçeği”" Tek Yönlü Varyans Analizi Sonuçları

\begin{tabular}{lccccccccc}
\hline $\begin{array}{l}\text { Okul } \\
\text { Türü }\end{array}$ & $\mathbf{N}$ & $\underline{\underline{X}}$ & $\mathbf{S}$ & $\begin{array}{l}\text { Varyansın } \\
\text { Kaynağı }\end{array}$ & $\begin{array}{c}\text { Kareler } \\
\text { Toplamı }\end{array}$ & Sd & $\begin{array}{c}\text { Kareler } \\
\text { Ortalamas }\end{array}$ & $\mathbf{F}$ & $\mathbf{p}$ \\
\hline \multirow{2}{*}{ Ilkokul } & 222 & 3.93 & 0.78 & $\begin{array}{l}\text { Gruplar } \\
\text { arası }\end{array}$ & 36.155 & 2 & 18.078 & 29.254 & $0.00^{*}$ \\
Ortaokul & 213 & 3.56 & 0.80 & Gruplar içi & 357.799 & 579 & 0.618 & & \\
Lise & 147 & 3.31 & 0.75 & Toplam & 393.954 & 581 & & & \\
\hline Toplam & 582 & 3.64 & 0.82 & & & & & & \\
\hline
\end{tabular}

${ }^{*} \mathrm{p}<.05$

Tablo 7 incelendiğinde okul müdürlerinin karizmatik liderlik ölçeğinden aldıkları puanların, öğretmenlerin okul türü değişkenine göre istatistiksel olarak anlamlı farklılık gösterip göstermediğini belirlemek için uygulanan Tek Yönlü Varyans Analizi sonucunda istatistiksel olarak anlamlı farklılık görülmektedir $(\mathrm{F}=29.254$, p<.05). Bu anlamlı farklılı̆̆ın kaynağını belirleyebilmek amacıyla tamamlayıcı post-hoc tekniklerini kullanabilmek için Levene's Testi uygulanmış olup varyansların homojen olduğu tespit edilmiştir (Levene $F=0.283$, p=0.754). Varyansların homojen olduğu durumlarda uygulanan post-hoc tekniklerinden LSD Çoklu Karşılaştırma Testi sonucunda, öğretmenlerin okul türü değişkenine göre karizmatik liderlik ölçeğinde ilkokul, ortaokul ve liselerde görev yapan öğretmenlerin puanları arasında istatistiksel olarak anlamlı bir farklılık görülmüştür. Bu anlamlı farklılık öğretmenlerin puan ortalamalarının yükseklik sıralamasında ilkokul, ortaokul ve lise şeklinde ortaya çıkmıştır. 
Tablo 8. Öğretmenlerin Kıdem Değişkenine Göre "Karizmatik Liderlik Ölçeği”" Tek Yönlü Varyans Analizi Sonuçları

\begin{tabular}{|c|c|c|c|c|c|c|c|c|c|}
\hline $\begin{array}{l}\text { Öğretmen } \\
\text { Kidem(yıl) }\end{array}$ & $\mathbf{N}$ & $\underline{X}$ & $S$ & $\begin{array}{l}\text { Varyansın } \\
\text { Kaynağı }\end{array}$ & $\begin{array}{c}\text { Kareler } \\
\text { Toplamı }\end{array}$ & Sd & $\begin{array}{c}\text { Kareler } \\
\text { Ortalaması }\end{array}$ & $\mathbf{F}$ & p \\
\hline $0-5$ Y 11 & 71 & 3.40 & 0.82 & $\begin{array}{l}\text { Gruplar } \\
\text { arası }\end{array}$ & 10.559 & 2 & 2.640 & 3.973 & $0.003^{*}$ \\
\hline 6-10 Y1l & 111 & 3.66 & 0.74 & Gruplar içi & 383.395 & 579 & 0.664 & & \\
\hline $11-15 Y_{11}$ & 123 & 3.71 & 0.84 & Toplam & 393.954 & 581 & & & \\
\hline $16-20 Y_{11}$ & 117 & 3.50 & 0.89 & & & & & & \\
\hline 21 ve üzeri & 160 & 3.78 & 0.77 & & & & & & \\
\hline Toplam & 582 & 3.64 & 0.82 & & & & & & \\
\hline
\end{tabular}

Tablo 8 incelendiğinde okul müdürlerinin karizmatik liderlik ölçeğinden aldıkları puanların, öğretmenlerin kıdem değişkenine göre istatistiksel olarak anlamlı farklılık gösterip göstermediğini belirlemek için uygulanan Tek Yönlü Varyans Analizi sonucunda istatistiksel olarak anlamlı farklılık görülmektedir $(\mathrm{F}=3.973$, $\mathrm{p}<.05)$. Bu anlamlı farklılı̆̆ın kaynağını belirleyebilmek amacıyla tamamlayıcı post-hoc tekniklerini kullanabilmek için Levene's Testi uygulanmış olup varyansların homojen olduğu tespit edilmiştir (Levene $F=1.403, p=0.231$ ). Varyansların homojen olduğu durumlarda uygulanan post-hoc tekniklerinden LSD Çoklu Karşılaştırma Testi sonucunda, karizmatik liderlik ölçeğinde öğretmenlerin kıdem değişkenine göre 0-5 yıl kıdeme sahip öğretmenlerin puanları ile 6-10 yıl, 11-15 yıl ve 21 yıl ve üzeri kıdeme sahip öğretmenlerin puanları arasında istatistiksel olarak anlamlı bir farklılık görülmüştür. 0-5 yıl kıdeme sahip öğretmenlerin puanlarının 6-10 yıl,11-15 yıl ve 21 yıl ve üzeri kıdeme sahip öğretmenlerin puanlarından düşük olduğu tespit edilmiştir.

Tablo 9. Okul Müdürlerinin Kıdem Değişkenine Göre “Karizmatik Liderlik Ölçeği” Tek Yönlü Varyans Analizi Sonuçları

\begin{tabular}{|c|c|c|c|c|c|c|c|c|c|}
\hline $\begin{array}{l}\text { Müdür } \\
\text { Kıdem }\end{array}$ & $\mathbf{N}$ & $\underline{X}$ & $S$ & $\begin{array}{l}\text { Varyansın } \\
\text { Kaynağı }\end{array}$ & $\begin{array}{l}\text { Kareler } \\
\text { Toplamı }\end{array}$ & Sd & $\begin{array}{c}\text { Kareler } \\
\text { Ortalaması }\end{array}$ & $\mathbf{F}$ & p \\
\hline $10-15 Y_{11}$ & 80 & 3.97 & 0.64 & $\begin{array}{l}\text { Gruplar } \\
\text { arası }\end{array}$ & 27.185 & 4 & 6.796 & 10.692 & $0.00^{*}$ \\
\hline $16-20 Y_{11}$ & 118 & 3.28 & 0.68 & Gruplar içi & 366.770 & 577 & 0.636 & & \\
\hline $21-25 Y_{11}$ & 194 & 3.69 & 0.76 & Toplam & 393.954 & 581 & & & \\
\hline 26-30 $\mathrm{Y}_{11}$ & 91 & 3.80 & 0.92 & & & & & & \\
\hline 31 Y1l Üz. & 99 & 3.55 & 0.95 & & & & & & \\
\hline Toplam & 582 & 3.64 & 0.82 & & & & & & \\
\hline
\end{tabular}

${ }^{*} \mathrm{p}<.05$ 
Tablo 9 incelendiğinde okul müdürlerinin karizmatik liderlik ölçeğinden aldıkları puanların, okul müdürlerinin kıdem değişkenine göre istatistiksel olarak anlamlı farklılık gösterip göstermediğini belirlemek için uygulanan Tek Yönlü Varyans Analizi sonucunda istatistiksel olarak anlamlı farklılık görülmektedir $(\mathrm{F}=10.692$, p<.05). Bu anlamlı farklılığın kaynağını belirleyebilmek amacıyla tamamlayıcı post-hoc tekniklerini kullanabilmek için Levene's Testi uygulanmış olup varyansların homojen olmadığı tespit edilmiştir (Levene F=3.612, p<.05). Varyansların homojen olmadığı durumlarda uygulanan post-hoc tekniklerinden Games Howell Çoklu Karşılaştırma Testi sonucunda, karizmatik liderlik ölçeğinde okul müdürlerinin kıdem değişkenine göre 10-15 yıl kıdeme sahip okul müdürlerinin puanı ile 16-20 yıl, 21-25 yıl ve 31 yıl ve üzeri kıdeme sahip okul müdürlerinin puanları arasında istatistiksel olarak anlamlı bir farklılık görülmüştür. 10-15 yıl kıdeme sahip okul müdürlerinin puanlarının 16-20 yıl,21-25 yıl ve 31 yıl ve üzeri kıdeme sahip okul müdürlerinin puanlarından yüksek olduğu tespit edilmiştir.

\section{Kurumsal İtibar Ölçeğine ilişkin Bulgular}

Öğretmenlerin görüşlerine göre okulların kurumsal itibar düzeylerinin, kurumsal itibar ölçeği ve alt boyutlarından aldıkları puanlarının, betimsel değerleri tablolarda verilmiştir.

Tablo 10. Öğretmenlerin Kurumsal İtibar Algılarına Yönelik Betimsel Değerler

\begin{tabular}{llll}
\hline Ölçek/Alt Boyutlar & N & $\underline{X}$ & SS \\
\hline Kurumsal İtibar & 582 & 3.88 & 0.60 \\
Hizmet Kalitesi & 582 & 4.16 & 0.55 \\
Yönetim Kalitesi & 582 & 3.82 & 0.85 \\
Finansal Sağlamlık & 582 & 3.74 & 0.81 \\
Çalışma Ortamı & 582 & 3.57 & 0.77 \\
Toplumsal Sorumluluk & 582 & 3.94 & 0.67 \\
Duygusal Çekicilik & 582 & 3.91 & 0.83 \\
Kurumsal Etik & 582 & 4.07 & 0.64 \\
\hline
\end{tabular}

Tablo 10 incelendiğinde öğretmenlerin görüşlerine göre okulların kurumsal itibar

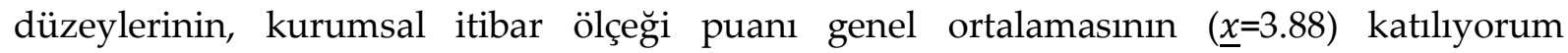
düzeyinde olduğu görülmektedir. Alt boyutlar incelendiğinde hizmet kalitesi alt boyutu $(\underline{x}=4.16)$, yönetim kalitesi alt boyutu $(\underline{x}=3.82)$, finansal sağlamlık alt boyutu $(\underline{x}=3.74)$, çalışma ortamı alt boyutu ( $\underline{x}=3.57)$, toplumsal sorumluluk alt boyutu ( $\underline{x}=3.94)$, duygusal çekicilik alt boyutu $(\underline{x}=3.91)$, kurumsal etik alt boyutu $(\underline{x}=4.07)$ ortalamasının da katıliyorum düzeyinde olduğu görülmektedir. 
Tablo 11. Öğretmenlerin Eğitim Durumu Değişkenine Göre “Kurumsal İtibar Ölçeği” Tek Yönlü Varyans Analizi Sonuçları

\begin{tabular}{lccclccccc}
\hline $\begin{array}{l}\text { Eğitim } \\
\text { Durumu }\end{array}$ & $\mathbf{N}$ & $\underline{X}$ & $\mathbf{S}$ & $\begin{array}{l}\text { Varyansın } \\
\text { Kaynağ }\end{array}$ & $\begin{array}{c}\text { Kareler } \\
\text { Toplamı }\end{array}$ & Sd & $\begin{array}{c}\text { Kareler } \\
\text { Ortalaması }\end{array}$ & F & p \\
\hline Ön Lisans & 43 & 4.24 & 0.40 & Gruplararası & 7.956 & 2 & 3.978 & 11.351 & $0.00^{*}$ \\
Lisans & 487 & 3.87 & 0.56 & Gruplariçi & 202.918 & 579 & 0.350 & & \\
Yüksek & & & & & & & & & \\
Lisans & 52 & 3.67 & 0.71 & Toplam & 210.874 & 581 & & \\
\hline Toplam & 582 & 3.88 & 0.60 & & & & & & \\
\hline
\end{tabular}

${ }^{*} \mathrm{p}<.05$

Tablo 11 incelendiğinde okulların kurumsal itibar düzeyi puanlarının, öğretmenlerin eğitim durumu değiş̧kenine göre istatistiksel olarak anlamlı farklılık gösterip göstermediğini belirlemek için Tek Yönlü Varyans Analizi uygulanmış, yapılan analiz sonucunda istatistiksel olarak anlamlı farklılık görülmektedir $(\mathrm{F}=11.351, \mathrm{p}<.05)$. Bu anlamlı farklılı̆̆ın kaynağını belirleyebilmek amacıyla tamamlayıcı post-hoc tekniklerini kullanabilmek için Levene's Testi uygulanmış olup varyansların homojen olmadığı tespit edilmiştir (Levene F=6.377, p<.05). Varyansların homojen olmadığı durumlarda uygulanan post-hoc tekniklerinden Games Howell Çoklu Karşılaştırma Testi sonucunda, okulların kurumsal itibar düzeyi puanlarında öğretmenlerin eğitim durumu değişkenine göre ön lisans mezunu puanları ile lisans ve yüksek lisans mezunu puanları arasında istatistiksel olarak anlamlı bir farklılık görülmüştür. Ön lisans mezunu öğretmenlerin puanlarının, lisans ve yüksek lisans mezunu öğretmenlerin puanlarından yüksek olduğu tespit edilmiştir.

Tablo 12. Öğretmenlerin Branş Değişkenine Göre "Kurumsal İtibar Ölçeği" Bağımsız Gruplar t-Testi Sonuçları

\begin{tabular}{lllllllc}
\hline Ölçek & Branş & $\mathbf{N}$ & $\underline{X}$ & SS & Sd & T & p \\
\hline \multirow{2}{*}{ Kurumsal İtibar } & Sınıf & 184 & 4.12 & 0.54 & 580 & 6.869 & $0.00^{*}$ \\
& Branş & 398 & 3.77 & 0.59 & & & \\
\hline
\end{tabular}

${ }^{*} \mathrm{p}<.05$

Tablo 12 incelendiğinde okulların kurumsal itibar düzeyi puanlarının aritmetik ortalamalarında, öğretmenlerin branş değişkenine göre istatistiksel olarak anlamlı farklılık görülmektedir ( $\mathrm{t}=6.869, \mathrm{p}<.05)$. Bu analiz sonucunda, sinıf öğretmenlerinin aritmetik ortalama puanlarının, branş öğretmenlerinin aritmetik ortalama puanlarından anlamlı olarak daha yüksek olduğu tespit edilmiştir.

Tablo 13. Öğretmenlerin Okul Türü Değişkenine Göre "Kurumsal İtibar Ölçeği”" Tek Yönlü Varyans Analizi Sonuçları 


\begin{tabular}{lccccccccc}
\hline $\begin{array}{l}\text { Okul } \\
\text { Türü }\end{array}$ & $\mathbf{N}$ & $\underline{\underline{X}}$ & $\mathbf{S}$ & $\begin{array}{l}\text { Varyansın } \\
\text { Kaynağı }\end{array}$ & $\begin{array}{c}\text { Kareler } \\
\text { Toplamı }\end{array}$ & Sd & $\begin{array}{c}\text { Kareler } \\
\text { Ortalaması }\end{array}$ & F & p \\
\hline İlkokul & 222 & 4.10 & 0.56 & $\begin{array}{l}\text { Gruplar } \\
\text { arası }\end{array}$ & 19.385 & 2 & 9.693 & 29.307 & $0.00^{*}$ \\
Ortaokul & 213 & 3.82 & 0.59 & Gruplar içi & 191.489 & 579 & 0.331 & & \\
Lise & 147 & 3.64 & 0.57 & Toplam & 210.874 & 581 & & & \\
\hline Toplam & 582 & 3.88 & 0.60 & & & & & & \\
\hline
\end{tabular}

${ }^{*} \mathrm{p}<.05$

Tablo 13 incelendiğinde okulların kurumsal itibar düzeyi puanlarının, öğretmenlerin okul türü değişkenine göre istatistiksel olarak anlamlı farklılık gösterip göstermediğini belirlemek için Tek Yönlü Varyans Analizi uygulanmış, yapılan analiz sonucunda istatistiksel olarak anlamlı farklılık görülmektedir $(\mathrm{F}=29.307, \mathrm{p}<.05)$. Bu anlamlı farklılığın kaynağını belirleyebilmek amacıyla tamamlayıcı post-hoc tekniklerini kullanabilmek için Levene's Testi uygulanmış olup varyansların homojen olduğu tespit edilmiştir (Levene $F=0.905, p=0.405$ ). Varyansların homojen olduğu durumlarda uygulanan post-hoc tekniklerinden LSD Çoklu Karşılaştırma Testi sonucunda, okulların kurumsal itibar düzeyi puanlarında öğretmenlerin okul türü değişkenine göre ilkokul ile ortaokul, ilkokul ile lise, ortaokul ile lisede görev yapan öğretmenlerin puanları arasında istatistiksel olarak anlamlı bir farklılık görülmüştür. Öğretmenlerin kurumsal itibar algı puanlarının yüksekten başlayarak sırasıyla ilkokul, ortaokul ve lise şeklinde sıralandıkları tespit edilmiştir.

Tablo 14. Öğretmenlerin Kıdem Değişkenine Göre "Kurumsal İtibar Ölçeği” Tek Yönlü

\begin{tabular}{|c|c|c|c|c|c|c|c|c|c|}
\hline $\begin{array}{l}\text { Öğretmen } \\
\text { Kidem }\end{array}$ & $\mathbf{N}$ & $\underline{X}$ & $\mathrm{~S}$ & $\begin{array}{l}\text { Varyansın } \\
\text { Kaynağı }\end{array}$ & $\begin{array}{c}\text { Kareler } \\
\text { Toplamı }\end{array}$ & Sd & $\begin{array}{c}\text { Kareler } \\
\text { Ortalamas1 }\end{array}$ & $\mathbf{F}$ & $p$ \\
\hline $0-5 Y_{11}$ & 71 & 3.73 & 0.69 & $\begin{array}{l}\text { Gruplar } \\
\text { aras1 }\end{array}$ & 5.008 & 4 & 1.252 & 3.509 & $0.008^{*}$ \\
\hline 6-10 Y Yl & 111 & 3.86 & 0.53 & $\begin{array}{l}\text { Gruplar } \\
\text { içi }\end{array}$ & 205.867 & 577 & 0.357 & & \\
\hline 11-15 Y11 & 123 & 3.94 & 0.59 & Toplam & 210.874 & 581 & & & \\
\hline $16-20 Y_{11}$ & 117 & 3.78 & 0.61 & & & & & & \\
\hline $\begin{array}{l}21 \text { yll ve } \\
\text { üzeri }\end{array}$ & 160 & 3.99 & 0.58 & & & & & & \\
\hline Toplam & 582 & 3.88 & 0.60 & & & & & & \\
\hline
\end{tabular}

${ }^{*} \mathrm{p}<.05$

Tablo 14 incelendiğinde okulların kurumsal itibar düzeyi puanlarının, öğretmenlerin kıdem değişkenine göre istatistiksel olarak anlamlı farklılık gösterip göstermediğini belirlemek için Tek Yönlü Varyans Analizi uygulanmış, yapılan analiz sonucunda istatistiksel olarak anlamlı farklılık görülmektedir ( $\mathrm{F}=3.509, \mathrm{p}<.05)$. Bu anlamlı farklılığın kaynağını belirleyebilmek amacıyla tamamlayıcı post-hoc tekniklerini kullanabilmek için Levene's Testi uygulanmış olup varyansların homojen olduğu tespit edilmiştir (Levene $F=2.284, p=0.059$ ). Varyansların homojen olduğu durumlarda uygulanan post-hoc tekniklerinden LSD Çoklu Karşılaştırma Testi sonucunda, okulların kurumsal itibar düzeyi puanlarında öğretmenlerin kıdem 
değişkenine göre 0-5 yıl kıdeme sahip öğretmenlerin puanları ile 11-15 yıl, 21 yıl ve üzeri kıdeme sahip öğretmenlerin puanları arasında istatistiksel olarak anlamlı bir farklılık görülmüştür. Bu analiz sonucunda 0-5 yıl kıdeme sahip öğretmenlerin puanlarının 11-15 yıl, 21 yıl ve üzeri kıdeme sahip öğretmenlerin puanlarından düşük olduğu tespit edilmiştir. Ayrıca 16-20 yıl kıdeme sahip öğretmenlerin puanları ile 11-15 yıl, 21 yıl ve üzeri kıdeme sahip öğretmenlerin puanları arasında istatistiksel olarak anlamlı bir farklılık görülmüştür. 16-20 yıl kıdeme sahip öğretmenlerin puanlarının 11-15 yıl ile 21 yıl ve üzeri kıdeme sahip öğretmenlerin puanlarından düşük olduğu tespit edilmiştir.

Tablo 15. Okul Müdürlerinin Kıdem Değişkenine Göre "Kurumsal İtibar Ölçeği'” Tek Yönlü Varyans Analizi Sonuçları

\begin{tabular}{|c|c|c|c|c|c|c|c|c|c|}
\hline $\begin{array}{l}\text { Müdür } \\
\text { Kıdem }\end{array}$ & $\mathbf{N}$ & $\underline{X}$ & $\mathrm{~S}$ & $\begin{array}{l}\text { Varyansın } \\
\text { Kaynağ1 }\end{array}$ & $\begin{array}{c}\text { Kareler } \\
\text { Toplamı }\end{array}$ & Sd & $\begin{array}{c}\text { Kareler } \\
\text { Ortalaması }\end{array}$ & $\mathbf{F}$ & p \\
\hline $10-15 Y_{11}$ & 80 & 4.16 & 0.43 & $\begin{array}{l}\text { Gruplar } \\
\text { arası }\end{array}$ & 14.616 & 4 & 3.654 & 10.743 & $0.00^{*}$ \\
\hline $16-20 Y_{11}$ & 118 & 3.63 & 0.54 & Gruplar içi & 196.259 & 577 & 0.340 & & \\
\hline $21-25 Y_{11}$ & 194 & 3.88 & 0.59 & Toplam & 210.874 & 581 & & & \\
\hline 26-30 $Y_{11}$ & 91 & 3.96 & 0.64 & & & & & & \\
\hline $\begin{array}{l}31 \text { Yil ve } \\
\text { üzeri }\end{array}$ & 99 & 3.89 & 0.63 & & & & & & \\
\hline Toplam & 582 & 3.88 & 0.60 & & & & & & \\
\hline
\end{tabular}

Tablo 15 incelendiğinde okulların kurumsal itibar düzeyi puanlarının, okul müdürlerinin kıdem değişkenine göre istatistiksel olarak anlamlı farklılık gösterip göstermediğini belirlemek için Tek Yönlü Varyans Analizi uygulanmış, yapılan analiz sonucunda istatistiksel olarak anlamlı farklılık görülmektedir $(\mathrm{F}=10.743$, p<.05). Bu anlamlı farklılığın kaynağını belirleyebilmek amacıyla tamamlayıcı post-hoc tekniklerini kullanabilmek için Levene's Testi uygulanmış olup varyansların homojen olmadığı tespit edilmiştir (Levene $\mathrm{F}=2.811, \mathrm{p}<.05$ ). Varyansların homojen olmadığ 1 durumlarda uygulanan post-hoc tekniklerinden Games Howell Çoklu Karşılaştırma Testi sonucunda, 10-15 yıl kıdeme sahip okul müdürlerinin görev yaptığı okulların kurumsal itibar düzeyi puanlarının 16-20 yıl, 21-25 yıl ve 31 yıl ve üzeri kıdeme sahip okul müdürlerinin görev yaptığı okulların kurumsal itibar düzeyi puanlarından yüksek olduğu tespit edilmiştir. 16-20 yıl kıdeme sahip okul müdürlerinin görev yaptığ1 okulların kurumsal itibar düzeyi puanlarının 21-25 yıl ve 26-30 yıl ile 31 yıl ve üzeri kıdeme sahip okul müdürlerinin görev yaptığı okulların kurumsal itibar düzeyi puanlarından düşük olduğu tespit edilmiştir.

\section{Okul Müdürlerinin Karizmatik Liderlik Özellikleri ile Okullarn Kurumsal İtibarı Arasındaki İlişkiye Yönelik Bulgular}


Okul müdürlerinin karizmatik liderlik özellikleri ile okulların kurumsal itibarı arasında bir ilişkinin olup olmadığını ortaya koymak için yapılan Pearson Korelasyon Analizi sonucunda, okul müdürlerinin karizmatik liderlik özellikleri ile okulların kurumsal itibarı arasında, pozitif yönde ve anlamlı düzeyde bir ilişki olduğu görülmüştür (Pearson $R=0.742$, $p<0.01$ ). Buna bağlı olarak Basit Doğrusal Regresyon Analizi Tekniği uygulanmış sonuçları Tablo 16'da verilmiştir.

Tablo 16. Okul Müdürlerinin Karizmatik Liderlik Özellikleri ile Okulların Kurumsal İtibarı Arasındaki İlişkiye Yönelik Regresyon Analizi Sonuçları

\begin{tabular}{llllll}
\hline Değişkenler & B & SHB & $\beta$ & T & p \\
\hline Sabit & 1.909 & 0.076 & & 25.078 & $0.000^{*}$ \\
Karizmatik Liderlik Ölçeği & 0.543 & 0.020 & 0.742 & 26.628 & $.0000^{*}$ \\
\hline
\end{tabular}

$\mathbf{R}=0.742, \mathbf{R}^{2}=0.550, \mathbf{p}=0.000, \mathbf{F}(709.050)=115.993$

Tablo 16 incelendiğinde basit doğrusal regresyon analizi sonucunda okul müdürlerinin karizmatik liderlik özelliklerinin okulların kurumsal itibarının bir yordayıcısı olduğu görülmüştür ( $\mathrm{F}=709.050, \mathrm{p}<.05)$. Okul müdürlerinin karizmatik liderlik özellikleri okulların kurumsal itibarındaki değişimin \%55'ini açılamaktadır.

\section{Tartışma, Sonuç ve Öneriler}

$\mathrm{Bu}$ araştırmada okul müdürlerinin karizmatik liderlik özelliklerinin okulların kurumsal itibarına etkisi incelenmiştir. Araştırmaya katılan öğretmenlerin görüşlerine göre okul müdürlerinin karizmatik liderlik özelliklerinin okulların kurumsal itibarındaki değişimin \%55'ini açıkladığ1 görülmüştür. Ayrıca öğretmenlerin görüşlerine öğretmenlerin cinsiyet, eğitim durumu, branş, okul türü, kıdem değişkenlerinde ve okul müdürlerinin kıdem değişkeninde anlamlı farklılık görülmüştür. Okul müdürlerinin eğitim durumu değişkeninde anlamlı farklılık görülmemiştir. Kurumsal itibarla ilgili öğretmenlerin eğitim durumu, branş, okul türü, kıdem değişkenlerinde ve okul müdürlerinin kıdem değişkeninde anlamlı farklılık görülmüştür. Öğretmenlerin cinsiyet değişkeninde ve okul müdürlerinin eğitim durumu değişkeninde anlamlı farklılık görülmemiştir.

Karizmatik Liderlik Ölçeği genel ortalamasının ve vizyon belirleme, çevresel duyarlılık, üye ihtiyaçlarına duyarlılık gösterme, statükoyu sürdürmeme alt boyutlarının katılıyorum düzeyinde olduğu, sıra dişı davranışlar sergileme ve kişisel risk üstlenme alt boyutlarının ise fikrim yok düzeyinde olduğu tespit edilmiştir. Bu sonuç Aladağ (2019), Alarçin (2020), Ballı (2018), Daşçı (2014), Işık (2016), Kocatürk (2007), Öncü (2017), Ponsombut, Kanokorn ve Sujanya (2014), Uysal ve Dönmez (2015) tarafından yapılan araştırma ile benzerlik göstermektedir. Arabacı ve Yüzer (2019) araştırmalarında okul müdürlerinin karizmatik liderlik özelliklerinin orta düzeyde olduğu sonucuna ulaşmıştır.

Öğretmenlerin cinsiyet değişkenine göre, okul müdürlerinin karizmatik liderlik özellikleri incelendiğinde istatistiksel olarak anlamlı farklılık görülmüş̧tür. Bu analiz sonucunda, erkek öğretmenlerin ortalamalarının kadın öğretmenlerin ortalamalarından yüksek olduğu tespit edilmiştir. Bu bulgulara göre erkek öğretmenlerin okul müdürlerinin karizmatik liderlik 
özelliklerine daha olumlu baktıkları söylenebilir. Cinsiyet değişkeni ile ilgili diğer çalışmalar incelendiğinde Alarçin (2020), Çelik (2011), Işık (2016), Karaköse (2008), Kocatürk (2007) ve Yüzer (2019) çalışmalarında bu araştırma sonuçları ile benzer sonuçlara ulaşmışlardır. Bu sonuçlardan farklı olarak Arabacı (2014), Buldu (2016), Çankaya (2019), Doğan (2007), Dönmez (2015), Kösele (2018) ve Sosik (2011)çalışmalarında cinsiyet değişkenine göre anlamlı farklılık bulunmadığını, Aladağ (2019) ve Boyraz (2018) ise kadın öğretmenlerin ortalamalarının daha yüksek olduğunu tespit etmişlerdir.

Öğretmenlerin eğitim durumu değişkenine göre, okul müdürlerinin karizmatik liderlik özellikleri incelendiğinde istatistiksel olarak anlamlı farklılık görülmüştür. Bu analiz sonucunda ön lisans mezunu öğretmenlerin puan ortalamalarının, lisans ve yüksek lisans mezunu öğretmenlerin puan ortalamalarından yüksek olduğu tespit edilmiştir. Bu bulguya göre lisans ve yüksek lisans mezunu öğretmenlerin beklentilerinin daha fazla olduğu söylenebilir. Eğitim durumu değişkeni ile ilgili diğer çalışmalar incelendiğinde Işık (2016) ve Kocatürk (2007) çalışmalarında bu sonuçlar ile benzer sonuçlara ulaşmışlardır. Bu sonuçlardan farklı olarak Aladağ (2019), Buldu (2016), Arıkan Kılıç ve Becerikli (2017), Çankaya (2019), ve Şakar (2016) çalışmasında eğitim durumu değişkenine göre anlamlı farklılık bulunmadığını tespit etmiştir.

Öğretmenlerin okul türü değişkenine göre, okul müdürlerinin karizmatik liderlik özellikleri incelendiğinde istatistiksel olarak anlamlı bir farklılık görülmüştür. Bu analiz sonucunda ilkokul, ortaokul ve lise puanları arasında istatistiksel olarak anlamlı farklılık görülmüştür. Puan sıralamaları yüksekten başlayarak ilkokul, ortaokul, lise şeklinde sıralanmıştır. Bu bulgulara göre okul müdürlerinin karizmatik liderlik özelliklerine en olumlu bakan öğretmenlerin ilkokullarda görev yapan öğretmenler olduğu söylenebilir. Bu durumun nedeni olarak ortaokul ve liselerde sınav kaygı ve stresinin olması, branş öğretmenlerinin ders programları ve ders dağıtımı ile ilgili problemlerin yaşanması, branş öğretmenlerinin beklentilerinin fazla olması ve bunlara bağlı olarak okul müdürü ile öğretmenler arası iletişimde ve etkileşimde çatışmanın kaçınılmaz olması söylenebilir. Bu kaygı ve stresin liselerde daha yüksek düzeyde yaşandığı söylenebilir. Okul türü değişkenine göre diğer çalışmalar incelendiğinde Kocatürk (2007) ve Yüzer (2019) benzer sonuçlara ulaşmışlardır. Bu sonuçlardan farklı olarak Aladağ (2019) okul türü değişkenine göre anlamlı farklılık bulunmadığını tespit etmiştir.

Öğretmenlerin kıdem değişkenine göre, okul müdürlerinin karizmatik liderlik özellikleri incelendiğinde istatistiksel olarak anlamlı farklılık görülmüştür. Yapılan analiz sonucunda 05 yıl kıdeme sahip öğretmenlerin puanlarının 6-10 yıl, 11-15 yıl ve 21 yıl ve üzeri kıdeme sahip öğretmenlerin puanlarından düşük olduğu tespit edilmiştir. Bu bulguya göre genç öğretmenlerin okul müdürlerinden daha fazla beklenti içerisinde oldukları söylenebilir. Kıdem değişkeni ile ilgili diğer çalışmalar incelendiğinde bu sonuçlar Kocatürk (2007) tarafından yapılan çalışma ile benzerlik göstermektedir. Bu sonuçlardan farklı olarak Alarçin (2020), Arabacı (2014), Çankaya (2019), Dönmez (2015), Yüzer (2019) çalışmasında kıdem değişkenine göre anlamlı farklılık bulunmadığını Aladağ (2019), Ballı (2018), Boyraz (2018), Pektaş (2019), Öncü (2017) ise kıdemi fazla olan öğretmenlerin ortalamalarının düşük olduğunu tespit etmişlerdir.

Okul müdürlerinin kıdem değişkenine göre, okul müdürlerinin karizmatik liderlik özellikleri incelendiğinde istatistiksel olarak anlamlı farklılık görülmüştür. Yapılan analiz sonucunda 1015 yıl kıdeme sahip okul müdürlerinin puanlarının 16-20 yıl, 21-25 yıl ve 31 yıl ve üzeri kıdeme 
sahip okul müdürlerinin puanlarından yüksek olduğu tespit edilmiştir. Bu bulguya göre öğretmenlerin, genç okul müdürlerinin karizmatik liderlik özelliklerine daha olumlu baktıkları söylenebilir.

Okulların kurumsal itibar düzeylerinin, kurumsal itibar ölçeği genel ortalamasında ve alt boyutlarının ortalamasında katıllyorum düzeyinde olduğu tespit edilmiştir. Bu sonuç Uslu (2018) ve Yurt (2012) ve tarafından yapılan çalışmalar ile benzerlik göstermektedir. İlker (2019) ve Özdoğru (2020) ise araştırmasında okulların kurumsal itibar düzeyini orta düzeyde katıliyorum şeklinde bulmuştur.

Öğretmenlerin cinsiyet değişkenine göre, okulların kurumsal itibar düzeyleri incelendiğinde istatistiksel olarak anlamlı farklılık görülmemiştir. Cinsiyet değişkeni ile ilgili diğer çalışmalar incelendiğinde Ataş (2012), Çantay (2018), Dülger (2017), Işık vd. (2016), İlker (2019), Kara (2014), Karali (2013), Karakaş (2019), Karaköse (2006), Taşdelen ve Taşlı (2019), Tüysüzoğulları (2010) ve Yurt (2012) bu araştırma ile benzer sonuçlara ulaşmışlardır. Bu sonuçlardan farklı olarak Çillioğlu (2010) ve Işık (2011) kadınlar lehine, Orçan (2015) ve Yılmaz (2015) ise erkekler lehine anlamlı farklılık bulunduğunu tespit etmişlerdir.

Öğretmenlerin eğitim durumu değişkenine göre, okulların kurumsal itibar düzeyleri incelendiğinde ön lisans mezunu öğretmenlerin puanları ile lisans ve yüksek lisans mezunu öğretmenlerin puanları arasında istatistiksel olarak anlamlı farklılık görülmektedir. Ön lisans mezunu öğretmenlerin ortalamalarının, lisans ve yüksek lisans mezunu öğretmenlerin ortalamalarından yüksek olduğu tespit edilmiştir. Bu bulguya göre ön lisans mezunu öğretmenlerin, okulların kurumsal itibarına yönelik algı düzeylerinin daha yüksek olduğu söylenebilir. Eğitim durumu değişkenine göre diğer araştırmalar incelendiğinde bu sonuçlardan farklı olarak Çantay (2018), Duran (2017), Dülger (2017), Kara (2014), Karali (2013), Karaköse (2006) ve Yurt (2012) tarafından yapılan çalışmalarda anlamlı farklılık bulunmadığı tespit edilirken, Orçan (2015) tarafindan yapılan çalışmada anlamlı farklılık tespit edilmiştir. Orçan (2015) tarafından yapılan araştırmada eğitim enstitüsü, ön lisans, lisans ve yüksek lisans mezunu öğretmenlerin olduğu gruplarda eğitim enstitüsü mezunu öğretmenlerin kurumsal itibar algılarının anlamlı olarak diğerlerinden düşük olduğu tespit edilmiştir.

Öğretmenlerin okul türü değişkenine göre, okulların kurumsal itibar düzeyleri incelendiğinde istatistiksel olarak anlamlı farklılık görülmüştür. Bu analiz sonucunda, öğretmenlerin okul türü değişkenine göre ilkokul, ortaokul ve lisede görev yapan öğretmenlerin puanları arasında istatistiksel olarak anlamlı bir farklılık görülmektedir. Öğretmenlerin puanlarının sırasıyla ilkokul, ortaokul ve lise şeklinde sıralandıkları görülmektedir. Bu bulguya göre kurumsal itibar algı puanları en yüksek olan öğretmenler ilkokullarda görev yapan öğretmenler, en düşük olan öğretmenler ise liselerde görev yapan öğretmenler olarak ifade edilebilir. Okul türü değişkenine göre diğer çalışmalar incelendiğinde Dülger (2017) ve Tüysüzoğulları (2010) çalışmalarında bu çalışma ile benzer sonuçlar elde etmişlerdir. Öğretim kademesi yükseldikçe öğretmenlerin kurumsal itibar algı düzeyinin düşmesinin bir sebebi ortaokul ve liselerin ilkokullara göre daha fazla personel ve öğrenci sayısına sahip olmasından kaynaklanmış olabilir.

Öğretmenlerin kıdem değişkenine göre, okulların kurumsal itibar düzeyleri incelendiğinde istatistiksel olarak anlamlı farklılık görülmüştür. Yapılan analiz sonucunda 0-5 yıl kıdeme sahip öğretmenlerin puanlarının 11-15 yıl, 21 yıl ve üzeri kıdeme sahip öğretmenlerin 
puanlarından düşük olduğu tespit edilmiştir. Bu bulguya göre genç öğretmenlerin okullara yönelik kurumsal itibar algı düzeylerinin daha düşük olduğu ve kurumdan daha fazla beklenti içerisinde oldukları söylenebilir.

Okul müdürlerinin kıdem değişkenine göre, okulların kurumsal itibar düzeyleri incelendiğinde istatistiksel olarak anlamlı farklılık görülmüştür. Yapılan analiz sonucunda 1015 yıl kıdeme sahip okul müdürlerinin görev yaptığı okulların kurumsal itibar düzeyi puanlarının 16-20 yıl, 21-25 yıl ve 31 yıl ve üzeri kıdeme sahip okul müdürlerinin görev yaptığ okulların kurumsal itibar düzeyi puanlarından yüksek olduğu tespit edilmiştir. Bu bulguya göre öğretmenlerin, genç okul müdürlerinin görev yaptığı kurumlara yönelik kurumsal itibar algılarının, daha olumlu olduğu söylenebilir. Bu durum kıdemi daha az okul yöneticilerinin daha genç ve dinamik yapıda olması, yenilikleri ve teknoloji kullanımında daha kıdemli müdürlere göre daha esnek olmalarından kaynaklanmış olabilir. Kıdemi daha düşük okul yöneticileri ile yüksekokul yöneticileri arasındaki kuşak farkı da böyle bir sonucun ortaya çıkmasında etkili olmuş olabilir. Bu nedenle farklı kıdemlerdeki okul yöneticilerinin belirli aralıklarla bir araya gelerek tecrübe paylaşımı yapmaları faydalı olabilir.

Okul müdürlerinin karizmatik liderlik özellikleri ile okulların kurumsal itibarı arasında yapılan analizler sonucu anlamlı düzeyde korelasyonel ilişki olduğu tespit edilmiştir. Okul müdürlerinin karizmatik liderlik özellikleri ile okulların kurumsal itibarı arasında ölçeğin genelinde ve tüm alt boyutlarında pozitif yönde ve anlamlı düzeyde bir ilişki olduğu görülmektedir. Bu bulguya göre okul müdürlerinin karizmatik liderlik özellikleri arttıkça okulların kurumsal itibarının da arttığı, okul müdürlerinin karizmatik liderlik özellikleri azaldıkça okulların kurumsal itibarının da azaldığı söylenebilir.

Okul müdürlerinin karizmatik liderlik özellikleri ile okulların kurumsal itibarı arasında anlamlı bir ilişki gözlenmiş, okul müdürlerinin karizmatik liderlik özelliklerinin okulların kurumsal itibarının bir yordayıcısı olduğu görülmüştür. Okul müdürlerinin karizmatik liderlik özellikleri okulların kurumsal itibarındaki değişimin \%55'ini açılamaktadır. Bu kapsamda okul müdürlerinin seçilmesi ve görevlendirilmesi aşamasında, Milli Eğitim Bakanlığının yazılı sınav sonuçları ile birlikte okul müdürü adaylarının liderlik özelliklerinin de göz önünde bulundurulmasını sağlayacak bir yapı oluşturması yararlı olacaktır. Hitabet gücü yüksek olan, üstün ikna kabiliyetine sahip ve insanları etkileyerek harekete geçirebilme özelliğine sahip karizmatik liderlik özelliklerine sahip okul müdürlerinin okulların kurumsal itibar algılarına olumlu yansıyacaktır. Ayrıca halen görevde bulunan okul müdürlerinin de karizmatik liderliğin önemli özelliklerinden olan hitabet gücü, ikna kabiliyeti konusundaki yetkinliklerinin daha da artırılabilmesi için hizmet içi eğitim faaliyetlerinden yararlanmaları sağlanabilir. Bununla birlikte farklı öğrenim kademlerindeki okul müdürlerinin bir araya geleceği okul yönetiminde iyi uygulamalar ve deneyim paylaşımı etkinlikleri düzenlenebilir. $\mathrm{Bu}$ etkinlikler internet üzerinden çevrimiçi olarak sanal toplantı araçları kullanılarak da yapılabilir. Böylece zaman, mekan ve bütçe kısıtlamalarının getirdiği engeller de aşılmış olur. 


\section{Kaynakça}

Aladağ, C. (2019). Lise müdürlerinin karizmatik liderlik özellikleri ile örgütsel sessizlik düzeylerinin incelenmesi (Yüksek Lisans Tezi, Yüzüncü Yıl Üniversitesi, Eğitim Bilimleri Enstitüsü, Van).

Alarçin, S. (2020). Okul müdürlerinin karizmatik liderlik davranışları ile öğretmenlerin örgütsel vatandaşlık davranışları arasındaki ilişki (Yüksek Lisans Tezi, Bahçeşehir Üniversitesi Eğitim Bilimleri Enstitüsü, İstanbul).

Antonakis, J., Fenley, M., \& Liechti S. (2011). Can charisma be taught? Tests of two interventions. Academy of Management Learning and Education, 10, 3, 374-396.

Arabacı, İ.B. (2014). Okul müdürlerinin karizmatik liderlik özellikleri ile öğretmenlerin örgütsel bağlılıkları arasındaki ilişki. Uluslararası Turkish Journal of Educational Studies, 1(1), 192-221.

Arıkan, E., Kılıç, G., \& Becerikli, G. (2017). Karizmatik liderlik ve örgütsel vatandaşlık davranışı arasındaki ilişki. Türk Turizm Araştırmaları Dergisi, 1 (4), 1-19.

Ataş, Ö. (2012). Öğretmen adaylarının okula yabancılaşma düzeyleri ve kurumsal itibar algıları arasındaki ilişkinin incelenmesi (Yüksek Lisans Tezi, Atatürk Üniversitesi Eğitim Bilimleri Enstitüsü, Erzurum).

Aydoğar, N., \& Yirci, R. (2020). Devlet ve özel okul yöneticilerinin yenilik yönetimi becerilerinin karşılaştırılması: Nicel bir araştırma. İstanbul Ticaret Üniversitesi Sosyal Bilimler Dergisi, 19(39), 1286-1308.

Aykanat, Z. (2010). Karizmatik liderlik ve örgüt kültürü ilişkisi üzerine bir uygulama (Yüksek Lisans Tezi, Karamanoğlu Mehmetbey Üniversitesi Sosyal Bilimler Enstitüsü, Karaman).

Barnett, M.L., Jermier, J.M., \& Lafferty, B.A. (2006). Corporate Reputation: The Definitional Landscape. Corporate Reputation Review, 9 (1), 26-38.

Bass, B. M. (1990). From transactional to transformational leadership: Learning to share the vision. Organizational Dynamics, 18(3), 19-31.

Başar, H. (1995). Eğitim denetçisi. Ankara: Pegem Yayınları.

Ballı, F. (2018). Öğretmen algılarına göre okul müdürlerinin gösterdiği karizmatik liderlik davranışlarının okullarda görülen örgütsel sessizliği yordama düzeyi Yüksek Lisans Tezi, Yıldız Teknik Üniversitesi, Sosyal Bilimler Enstitüsü, İstanbul.

Beyer, J. M. (1999). Taming and promoting charismato change organizations. The Leadership Quarterly, 10(2), 307-330.

Boyraz, A. (2018). Özel eğitim okulu müdürlerinin liderlik stillerinin okul kültürüne ve iklimine etkisi (Yüksek Lisans Tezi, Yeditepe Üniversitesi Eğitim Bilimleri Enstitüsü, İstanbul).

Bryman, A. (1993). Charismatic leadership in business organizations: Some neglected issues. The Leadership Quarterly, 4(3-4), 289-304.

Buldu, T. (2016). Karizmatik liderlik ve çalışan performansı ilişsisi: Bir örnek olay araştırması (Yüksek Lisans Tezi, Okan Üniversitesi Sosyal Bilimler Enstitüsü, İstanbul).

Bursalığlu, Z. (2000). Okul yönetiminde yeni yapı ve davranış. Ankara: Pegema Yayıncılık.

Büyüköztürk, Ş. (2007). Sosyal bilimler için veri analizi el kitabı. Ankara: Pegema Yayıncılık. 
Can, A. (2016). SPPS ile bilimsel araştırma sürecinde nicel veri analizi. Ankara: Pegema Yayıncılık.

Chun, R. (2005). Corporate Reputation: Meaning and Measurement. International Journal of Management Reviews, 7(2), 91-109.

Conger, J. A., \& Kanungo, R. (1987). Toward a behavioral theory of charismatic leadership in organizational settings. Academy of Management Review, Vol. 12, No: 4, 637-647.

Conger, J.A., \& Kanungo, R. (1994). Charismatic leadership in organizations: Perceived behavioral attributes and their measurement. Journal of Organizationa lBehavior 15, 439-452.

Cornejo, C.P., Garcia J.B.D. \& Puente, E.Q., (2019). How to manage corporate reputation? The effect of enterprise risk management systems and audit committees on corporate reputation. European Management Journal 37 (2009) 505-515.

Cravens, K.S., \& GoadOliver, E. (2006). Employees: The key link to corporate reputation management. Business Horizons, 49 (4), 293- 302.

Çankaya, B.Ö. (2019). Yöneticilerin Karizmatik Liderlik Özellikleriyle Çalışanların İş Tatmini Arasındaki İlişkiyi İncelemeye Yönelik Bir Araştırma (Yüksek Lisans Tezi, İstanbul Üniversitesi Sosyal Bilimler Enstitüsü, İstanbul).

Çantay, N. (2018). Kurumsal İtibar Algısında Örgüt İçi İletişimin Rolü: Ĕ̆itim Kurumlarında Bir Araştırma (Yüksek Lisans Tezi, Bahçeşehir Üniversitesi Sosyal Bilimler Enstitüsü, İstanbul).

Çelik, V.O. (2011). Basketbol Oyuncularının Görüşlerine Göre Antrenörlerin Karizmatik Liderlik Özelliklerinin Takımın Bütünlüğ̈̈ne Etkisi (Doktora Tezi, Anadolu Üniversitesi Sosyal Bilimler Enstitüsü, Eskişehir).

Çillioğlu, A. (2010). İç ve dış paydaşların değerlendirmelerine göre Anadolu Üniversitesinin kurumsal itibarı (Yüksek Lisans Tezi, Anadolu Üniversitesi Sosyal Bilimler Enstitüsü, Eskişehir).

Doğan, S. (2007). Vizyona dayalı liderlik. İstanbul: Kare Yayınları.

Duran, İ. (2017). Özel sektör çalışanlarının örgüt kültürü ve karizmatik liderlik özelliklerinin bazı değişkenler açısından incelenmesi. Uluslararası Turkish Journal of Educational Studies, 1(1).

Dönmez, S.U. (2015). İlkokul öğretmenlerinin görüşlerine göre okul müdürlerinin karizmatik liderlik davranışları ve empatik eğilimleri (Yüksek Lisans Tezi, İstanbul Aydın Üniversitesi Sosyal Bilimler Enstitüsü, İstanbul).

Dülger, G. (2017). Özel okullarda kurumsal itibar algısı: Antalya Özel Envar Okulları paydaşları üzerinde bir araştırma (Yüksek Lisans Tezi, Süleyman Demirel Üniversitesi Sosyal Bilimler Enstitüsü, Isparta).

Fombrun, Charles F. (1996). Reputation: Realizing value from the corporate rmage. Boston: Harvard Business School Press.

Fiol, C.M., Harris, D., \& House, R. (1999). Karizmatik liderlik: Sosyal değişimi etkileme stratejileri. The Leadership Quarterly, 10 (3), 449-482.

Gül, H. (2003). Karizmatik liderlik ve örgütsel bağlılık ilişkisi üzerine bir araştırma (Doktora Tezi, Gebze İleri teknoloji Enstitüsü Sosyal Bilimler Enstitüsü, Gebze).

Hall, R. (1993). A frame work linking intangible resources and capabilities to sustainable competitive advantage. Strategic Management Journal, 14(8), 607-618. 
House, R.J. (1977). A 1976 Theory of Charismatic Leadership", Hunt, J. G. ve Larson, L.L. (Ed.), Leadership: The Cutting Edge. Carbondale: Southern Illinois University Press, s. 189-207.

Işık, B. (2016). İlkokul müdürlerinin karizmatik liderlik özellikleriyle okullarındaki öğretmenlerin motivasyonu arasındaki ilişki (Yüksek Lisans Tezi, Yüzüncü Yıl Üniversitesi Eğitim Bilimleri Enstitüsü, Van).

Işık, M., Çiçek, B., \& Almalı, V. (2016). Üniversitelerin iç paydaşlarının kurumsal itibar algısını ölçmeye yönelik bir araştırma. Bitlis Eren Üniversitesi Sosyal Bilimler Enstitüsü Dergisi,5(2016), 163-180.

Işık Yılmaz, E. (2011). Yükseköğretim kurumlarında kurumsal itibarın öğrenci tercihleri üzerindeki rolü: Vakıf üniversitelerinde bir araştırma (Doktora Tezi, İstanbul Üniversitesi Sosyal Bilimler Enstitüsü, İstanbul).

İlker, İ. (2019). Okul yöneticilerinin kurumsal itibar algılarıyla örgütsel bağlllık düzeyleri arasındaki ilişkinin belirlenmesi (Yüksek Lisans Tezi, Dumlupınar Üniversitesi Sosyal Bilimler Enstitüsü, Kütahya).

Jackson, K. (2004). Building reputational capital. New York: Oxford University Press.

Kara, A.İ. (2014). Kurumsal kültür, kurumsal kimlik ve kurumsal imajın kurumsal itibar üzerine etkileri, bir işletme örneği (Yüksek Lisans Tezi, Beykent Üniversitesi Sosyal Bilimler Enstitüsü, İstanbul).

Karakaş, N.N. (2019). Özel ilkokulların kurumsal itibarı konusunda yönetici öğretmen ve veli görüşleri: Malatya örneği (Yüksek Lisans Tezi, İstanbul Üniversitesi Lisansüstü Eğitim Enstitüsü, İstanbul).

Karaköse, T. (2006). Eğitim örgütlerindeki iç ve dış paydaşların kurumsal itibara ilişkin algılamaları (Yayımlanmamış Doktora Tezi, Fırat Üniversitesi Sosyal Bilimler Enstitüsü, Elazığg).

Karaköse, T. (2007). Örgütlerde itibar yönetimi. Akademik Bakış, 11, 1-12.

Karaköse, T. (2008). Okul müdürlerini itibarlı kılan değerlerin belirlenmesine yönelik nitel bir çalışma. Değerler Ĕ̆itimi Dergisi, 6(16), 113-129.

Karaköse, T. (2008). An Evaluation on Principals' Managerial Behaviors: The Profile of Principal from the Teachers' Point of View. World Applied Sciences Journal, 3(1), 67-72.

Karaköse, T. (2014). The empirical study of organizational justice and job satisfaction for highschool teachers in Turkey. Pakistan Journal of Statistics, 30(6), 1243-1250.

Karali, H. (2013). Kurumsal itibar ile çalışanların örgüte bağhlıkları arasındaki ilişki ve bir uygulama (Yüksek Lisans Tezi, Marmara Üniversitesi Sosyal Bilimler Enstitüsü, İstanbul).

Karasar, N. (2010). Bilimsel araştırma yöntemi. Ankara: Nobel Yayın Dağıtım.

Kocatürk, A. (2007). Meslek lisesi müdürlerinin karizmatik liderlik davranışları incelenmesi Yüksek Lisans Tezi, Yeditepe Üniversitesi Sosyal Bilimler Enstitüsü, İstanbul.

Kösele, M. (2018). Karizmatik liderlik davranışlarının kadın ve erkek iş gücü açısından karşılaştırılması: Bir araştırma (Yüksek Lisans Tezi, Kocaeli Üniversitesi Sosyal Bilimler Enstitüsü, Kocaeli).

Levay, C. (2010). Charismatic leadership in resistance to change. The Leadership Quarterly, 21(1), 127-143. 
Meindl, J.R. (1990). On leadership: An alternative to the conventional wisdom, Staw, B.M. ve Cummings, L.L. (Ed.), Research in Organizational Behavior, 12. Greenwich, Connecticut: JAI Press.

Orçan, A. (2015). İzmir ili merkez ilçeleri anadolu liselerindeki öğretmenlerin okullarının kurumsal itibarına ve müdürlerinin liderliğine ilişkin algıları (Yüksek Lisans Tezi, Dokuz Eylül Üniversitesi Eğitim Bilimleri Enstitüsü, İzmir).

Özdoğru, M. (2020). Okul yöneticilerinin öğretimsel liderlik davranışları ile kurumsal itibar algısı arasındaki ilişki (Doktora Tezi, Gazi Üniversitesi Eğitim Bilimleri Enstitüsü, Ankara).

Pektaş, H.M. (2019). Öğretmen algılarına göre okul müdürlerinin liderlik tarzı ile örgütsel sessizlik arasındaki ilişkinin analizi (Yüksek Lisans Tezi, İnönü Üniversitesi Eğitim Bilimleri Enstitüsü, Malatya).

Ponsombut, S., Kanokorn, S., \& Sujanya, S. (2014). Factor saffecting charismatic leadership of primary schools principals. Procedia - Social and Behavioral Sciences 112 (2014), 962 - 967.

Shamir, B. (1992). Attribution of İnfluence and charisma totheleader: Theromance of leadershiprevisited. Journal of Applied Social Psychology, 22,386-407.

Shamir, B.,House, R. J., \& Arthur, M. B. (1993). The motivational effects of charismatic leadership: A self concept-based theory. Organization Science, 4, 577-594.

Sosik, J.J., Juzbasich, J., \& Chun, J.U. (2011). Effects of moral reasoning and management level on ratings of charismatic leadership, in-role and extra-role performance of managers: A multi-source examination. The Leadership Quartely 22 (2011), 434-450.

Şakar, M. (2016). Okul yöneticilerinin liderlik tarzları ile işe olan yaratıcı katılımları arasındaki ilişkinin incelenmesi (Yüksek Lisans Tezi, İstanbul Sabahattin Zaim Üniversitesi Sosyal Bilimler Enstitüsü, İstanbul).

Şişman, M.,\&Turan, S. (2004). Eğitim ve okul yönetimi. Ankara: Pegema Yayıncılık.

Tak, B.,\&Çiftçioğlu, A. (2009). Algılanan örgütsel prestij ile örgütsel bağlılık ve örgütsel özdeşleşme arasındaki ilişkilerin incelenmesine yönelik bir araştırma. Akdeniz Üniversitesi İ.̇.B.F Dergisi, (18), 110-116.

Taşdelen, B., \& Taşlı, H. (2019). Kurumsal itibarın ölçülmesi: Gümüşhane Üniversitesinin iç paydaşları tarafından algılanışı. Karadeniz Teknik Üniversitesi İletişim Fakültesi Elektronik Dergisi, Cilt 6 (17)

Tüysüzoğulları, E. (2010). Ortaöğretim kurumlarında yönetici ve öğretmenlerin kurumsal itibara ilişkin algılamaları: Kastamonu uygulaması (Yüksek Lisans Tezi, Dumlupınar Üniversitesi Sosyal Bilimler Enstitüsü, Kütahya).

Waldman, D. A., \& Javidan, M. (2009). Alternative forms of charismatic leadership in the integration of mergers and acquisitions. The Leadership Quarterly, 20(2), 130-142.

Weber, M. (1947). The theory of economic and social organization (Trans. A. M. Henderson and Talcott Parsons). New York: Oxford University Press.

Yirci, R. \& Berk, B. (2021). Okul Yöneticilerinin ve Öğretmenlerin Görüşlerine göre Etkili Okul Müdürü: Nitel bir Araştırma. Journal of History School, 50, 570598.http://dx.doi.org/10.29228/Joh.43166 
Yirci, R., \& Karaköse, T. (2010). Democratic education policy and Turkish education system. Procedia Social and Behavioral Sciences, 9, 1330-1334.

Yirci, R., \& Kurtulmus, O. F. (2018). Just a Leader or Servant Leader: How Do Teachers Perceive Their School Principals? Üniversitepark Bülten, 7(1), 40-50.

Yirci, R., Özdemir, T. Y., Kartal, S. E., \& Kocabaş, İ. (2014). Teachers' perceptions regarding school principals' coaching skills. School Leadership\& Management, 34(5),454-469.

Yılmaz, M. (2015). Kurumsal itibar yönetimi algısının örgütsel bağgllık üzerindeki etkisi (Yüksek Lisans Tezi, Türk Hava Kurumu Sosyal Bilimler Enstitüsü, Ankara).

Yukl, G. (1999). An evaluation of conceptual weaknesses in transformational and charismatic leadership theories. The Leadership Quarterly, 10(2), 285-305.

Yurt, İ. (2012). Kurumsal itibar yönetimi algısının örgütsel bağlllk üzerindeki etkisi: Düzce Üniversitesi örneği (Yüksek Lisans Tezi, Düzce Üniversitesi Sosyal Bilimler Enstitüsü, Düzce).

Yüzer, B. (2019). Okul müdürlerinin karizmatik liderliközellikleri ile okul öncesi öğretmenlerinin okul kültürü algıları arasındaki ilişkinin incelenmesi (Yüksek Lisans Tezi, Marmara Üniversitesi Eğitim Bilimleri Enstitüsü, İstanbul). 